Nabil Baldi,

Université de la Cote d'Azur, Institut de l'administration des entreprises de Nice, France

iD ORCID ID,0000-0001-7123-3547

email: nabil.baldi01@gmail.com

\title{
MANAGEMENT OF INNOVATIONS IN PUBLIC GOVERNANCE: QUALITY MANAGEMENT SYSTEM, MANAGEMENT CONTROLLING AND INTERNAL AUDITING APPROPRIATION
}

Abstract. The race for performance has led some public service organizations to put in place some management innovations such as the implementation of organizational control. Organizational control is a system, a set of mechanisms and tools such as Quality management system, Management controlling, Internal auditing etc that affects all levels of the organization (strategic and operational levels), to master the decision-making processes, actions and results. Those organizational control tools don't bring all expected effects because they are under-used. Internal auditing is used mainly for compliance procedures, management controlling for budgeting and Quality Management, a system for the prescription of procedures which is only a small percentage of the potential functionalities of these tools used punctually or inducing inappropriate behaviours. Those behaviours deprive these organizations of a significant source of synergies and performance. Those observations led to the questions of change management, learning organization, etc that can be included in a general question of appropriation of controlling tools considering Simultaneity Dimension (Simultaneous deployment of those tools), an original dimension little studied in research on appropriation and which corresponds more to the reality of those companies. Appropriation refers to two conceptions. Appropriation as a process inducing the acquisition of knowledge or behaviours concerning an object. Appropriation as a state which implies the assessment of the gap between how an object is integrated by users and its conceptual definition. Appropriation implies consistency between an object and its use. This research is a multiple case study comparing 3 companies, which allowed the enrichment of the appropriation model proposed by De Vaujany (2006) by specifying the predictive factors affecting each of the phases of this process of appropriation of control tools (Internal Auditing, Management controlling and Quality Management System) including the impact of simultaneity in the context of public service organizations in Morocco. For managerial use, those models constitute a frame or a diagnosis methodology to assess the appropriation of organizational control tools for the stimulation of their usage and therefore improve the multidimensional performance of the public service and citizen's satisfaction.

Keywords: Appropriation, simultaneity, integrated system, organizational control, public governance, public management.

Introduction. Public services are among the most controlled organizations by regulation authorities, by investors, by customers/ users or their representatives etc (Quach, et al., 2020; Brignall \& Modell, 2000). Thus, these organizations in their efforts to consider stakeholders' expectations have made available to their managers a range of control tool.

Despite the implementation of those organizational control tools, the fact remains that information management and the process of decisions don't reach the expected effectiveness. Numerous attitudes indicate a certain difficulty of application such as:

1. Underuse of the functionalities of organizational control tools:

Thus, internal auditing which allows the Development and updating of benchmarks, to carry out Audit tests (third party circularization, tests, inventories etc), to issue Recommendations (Reports, FRAP, monitoring of action plans, etc), to Measure effectiveness, to assess risks, to provide Advice, is used only for compliance audits.

Cite as: Baldi, N. (2020). Management of Innovations in Public Governance: Quality Management System, Management Controlling and Internal Auditing Appropriation. Marketing and Management of Innovations, 2, 95-107. http://doi.org/10.21272/mmi.2020.2-07 
Management controlling which allows the elaboration of Performance indicators and KPIs, Dashboards, budgets (Exploitation, Investment, Turnover, Cash etc), Reporting, the Planning and modelling, the Analysis of costs and performances, the assessment of projects is used only for budget management.

A quality management system which allows the review of Processes, to develop Control charts, to produce dashboards for performance monitoring, the Transcription and Process Mapping (flowchart, PERT etc.), to deploy Analysis methods (causal analysis, PARETO etc) for process security and traceability (FMEA, GANT etc) is mainly used for transcription of procedures.

2. Occasional use of organizational control tools:

Backdated documents the day before internal or quality audits, the irregular frequency in the use of tools led us to this observation.

Public service companies in their unrestrained race for performance often embark on several modernization fronts by simultaneously implementing a range of management tools without achieving the expected performance.

The implementation of management tools is a necessary condition for modernizing public service companies, but it is not enough for these companies to be efficient.

The performance level and appropriation of controlling tools are correlated. It is a postulate for this research. The purpose, on the other hand, is to identify factors which improve their appropriation when they are deployed simultaneously.

These observations led us to ask the question of the appropriation of control tools from the perspective of organizational structures, animation of the processes, sharing of roles and powers, and scheduling of activities. Thus, the research question is as follows:

What are the factors that stimulate the appropriation of the organizational control tools deployed simultaneously within public service companies?

To answer this question, the following subsidiary questions should be addressed: what are the implemented functionalities? Is the organizational configuration compatible with the environment in which the organization operates? does this promote the appropriation of organizational control tools? What are the means available and how to assess the level and the quality of appropriation?

The purpose of this research is to make intelligible the process of appropriation in the context of public service organizations in Morocco by proposing specific schemes for the appropriation of organizational control tools deployed simultaneously. The proposed schemes could thus constitute a diagnostic tool making it possible to frame reflection and suggest areas to improve performance.

Literature Review. Many studies on management tools have attempted to apprehend them from different perspectives (Peirce, 1978; Berrebi-Hoffmann \& Boussard, 2005, Grimand, 2006) nevertheless, the effect of simultaneity on the appropriation of organizational controlling tools has not been explicitly addressed in management sciences. Therefore, this research covers the two concepts, Appropriation and Simultaneity, in a joint way «Simultaneous Appropriation» which corresponds to the simultaneous deployment of several objects.

The appropriation of management tools has become a major issue due to their multiplication. The theory of appropriation attempts to provide answers to the difficulties inherent in this process (Gauche; 2013).

To answer the research question, De Vaujany's Approach of Appropriation (De Vaujany, 2006) apprehend Appropriation by covering the following 3 complementary perspectives:

- Rational perspective (Rogers, 1998): which assimilates Appropriation to adoption and insists on the technical dimension of the tool to encourage its adoption. Roger's model talks about the endogenous and exogenous factors of adoption (relative advantage, compatibility, ease of use, observability of effects, direct externalities or number of users, indirect externalities or interfaces, reinvention); 
- $\quad$ Sociopolitical perspective (Akrich, 1993): which indicates the non-linear and iterative nature of the appropriation and insists on the role of mediation for the interest of potential users;

- Psycho-cognitive perspective (Giddens, 1987, Weick, 1995).

Inspired by the contributions of Giddens' (1987) theory of structural duality, thus a tool can be restrictive and have an enabling character at the same time, and Weick's (1995) sensemaking theory which establishes the continuous and recursive link between action and cognition which allows the organization to evolve.

These complementary perspectives of appropriation indicate that the user is an actor about the patterns of use offered to him. Indeed, by its interpretation, he invests the tool with its logics which may be different from the rationality initially planned by the designer.

De Vaujany's model has five non-linear steps:

1. Evocation, Ecological change, or Discontinuity is linked to an ambiguity resulting from the environment of the organization which evokes the object.

2. Enactment corresponds to the different ways of acting following the occurrence of the change.

3. Selection of environmental signals allows the justification of privileged actions and the creation of meaning.

4. Retention helps to retain the most effective actions based on the creation of meaning.

5. Memory makes it possible to reactivate what has been memorized (the cognitive cards memorized) in new configurations or situations and this in the light of the cognitive diagrams establishing the links between a way of acting, effects and level of effectiveness.

Simultaneity, an original contextual dimension.

The link between the notion of simultaneity and organizational control has been grasped by a few works through the analysis of the interrelationships between different organizational control systems as indicated by Hanzlich and Bruhl (2013) in their article entitled «Management control systems as a package». In these works, simultaneity has often been assimilated to concepts such as cooperation, organizational layout or integration.

The latter notion is difficult to operationalize within organizations (Grandgirard, 2007). Certain theories have made it possible to apprehend it by linking it to certain intrinsic or extrinsic dimensions of the organization such as the theory of differentiation-integration of Lawrence and Lorsch (1967) which establishes a correlation between the degree of differentiation (or specialization) of structures and degree of sophistication of integration mechanisms. To be effective, the organizational system must be designed following the organizational context of the company, its environment, its strategy, its size, its structures etc.

The theory of Lawrence and Lorsch can constitute a theoretical framework allowing to integrate this notion of simultaneity. This theory, about the contingent school, is one of the major theories (Silaen \& Williams, 2009), which attempts to account for how organizations are structured by studying the influence of context variables (environmental stability among others) on the characteristics of organizations. It provides explanations for integration practices.

The aim of this article is to make the process of appropriation intelligible by detecting the factors allowing to favourably influence each sequence of the process of appropriation (as described by De Vaujany) of organizational controlling tools deployed simultaneously in public service organizations.

The conclusions of this article can be used as a frame to assess the appropriation of the organizational control tools and consequently to be able to suggest progress axes to improve the quality of service and the performance of their organization in general.

Methodology and research methods. Even though the subject of control occupies a central position in studies of organizations (Silva, 2003), the fact remains that the appropriation of organizational control tools as an object of study has not been dealt with so plethorically unlike the appropriation of other objects such as NICT (Gauche, 2013) 

Internal Auditing Appropriation

The two phenomena, organizational control and organization, are artefacts; the way of apprehending the research question is inspired by our experience within these organizations; the complexity of the interactions induced by the diversity of actors and phenomena affecting public service organizations; the objective of the research which is to understand the different interpretations and meanings constructed by actors of organizations in connection with the phenomenon of appropriation and that the scheme to establish doesn't pretend to constitute a universal law. Relativistic ontology and Critical realism (Van de Ven, 2007) are more coherent with the research question.

This epistemological position has been operationalized through a mixed methodology (Creswell, 2003). This approach would comfort the validity of constructs thanks to a methodological triangulation. To this end, the following analysis process was realized:

- Development of a coding matrix, based on the theoretical corpus (97 codes).

- Documentary content analysis (Wanlin, 2007) based on internal documents specific to each field (28 documents analyzed).

- Perceptual analysis (Usunier, 2000); based on interviews with a panel of 15 profiles, based on a semi-structured direct administration interview guide made up of 22 questions.

- Development of a questionnaire (45 questions) based on the results of the previous steps, covering all of the potential explanatory factors.

- Analysis of responses collected via an MCA (Multiple Correspondence Analysis) for the identification of groups of homogeneous profiles because of the nature of their responses and their positioning to the proposed measurement variables (dissemination and quality of appropriation).

- Identification of the differentiating measurement variables also called variables to be predicted via an analysis of mixed data (PCAMIX) given the number of measurement variables ( 6 variables).

- Identification of predictive variables through the generation of classification trees and regression rules.

- Evaluation of the predictive force of the explanatory factors to the six measurement variables to be predicted by generating new regression rules.

- Proposal of conceptual diagrams based on the regression rules generated.

MCA, PCAMIX, correlation tables, regression rules and classification and regression trees were edited thanks to XL Stat 2019.

3 cases of public service companies based in Morocco with common characteristics and others of differentiation were selected. It's about:

- a private company for the distribution of Water and Electricity listed on the stock exchange market (Utility Company);

- a division of a public establishment which ensures the distribution of Electricity (Public Office);

- a private company that manages the waste collection and cleaning (Urban Cleaning Company).

The analyzed cases allow the representativeness of at least 3 models of public service companies thus comforting the validity of the empirical research. Table 1 below highlights the differences between the 3 studied cases.

Because of the diversity of organizational control tools that exist, three tools linked to the question of performance and which can fit into one of the uses proposed by Chia (2003): Regulation, hierarchical or functional power, management were selected. These are Management Controlling, Internal Auditing and the Quality Management System. 
N., Baldi. Management of Innovations in Public Governance:Quality Management System, Management Controlling and Internal Auditing Appropriation

Table 1. Comparative matrix of the characteristics of the 3 organizations

\begin{tabular}{|c|c|c|c|}
\hline Case & $\begin{array}{l}\text { Private Company listed on the } \\
\text { stock exchange market }\end{array}$ & Urban Cleaning Company & $\begin{array}{c}\text { Public Office - } \\
\text { Branche Electricite }\end{array}$ \\
\hline Legal Form & Public limited Cie & $\begin{array}{l}\text { Limited liability company sole } \\
\text { shareholder }\end{array}$ & $\begin{array}{l}\text { The public industrial and } \\
\text { commercial establish- } \\
\text { ment }\end{array}$ \\
\hline Size & Big business & $\begin{array}{l}\text { small and medium-sized enter- } \\
\text { prise }\end{array}$ & big business \\
\hline $\begin{array}{l}\text { Economical perfor- } \\
\text { mance }\end{array}$ & Profit Result & Lossdeficit & Lossdeficit \\
\hline $\begin{array}{l}\text { Nature of the Public } \\
\text { service }\end{array}$ & $\begin{array}{l}\text { The delegated management contract } \\
\text { for the distribution of drinking water, } \\
\text { electricity, liquid sanitation and public } \\
\text { lighting management in the city of } \\
\text { Casablanca }\end{array}$ & $\begin{array}{c}\text { Delegated management contract } \\
\text { of the urban property of } 4 \text { pre- } \\
\text { fectures in the city of Casa- } \\
\text { blanca }\end{array}$ & $\begin{array}{l}\text { Production, Transport } \\
\text { and Distribution of Elec- } \\
\text { tricity }\end{array}$ \\
\hline $\begin{array}{l}\text { Supervisory author- } \\
\text { ity }\end{array}$ & $\begin{array}{c}\text { Ministry of the Interior - Directorate of } \\
\text { Delegated Management and Local } \\
\text { Authorities }\end{array}$ & $\begin{array}{l}\text { Ministry of the Interior - Direc- } \\
\text { torate of Delegated Manage- } \\
\text { ment and Local Authorities }\end{array}$ & $\begin{array}{l}\text { Ministry of Energy and } \\
\text { Mines }\end{array}$ \\
\hline DelegatingAuthority & Urban Municipality of Casablanca & $\begin{array}{l}\text { Urban Municipality of Casa- } \\
\text { blanca }\end{array}$ & NA \\
\hline ControllingAuthority & $\begin{array}{c}\text { Urban Municipality of Casablance via } \\
\text { a permanent Control Service }\end{array}$ & $\begin{array}{c}\text { Urban Municipality of Casa- } \\
\text { blance via a mixed local devel- } \\
\text { opment company (Casa Presta- } \\
\text { tions) }\end{array}$ & $\begin{array}{l}\text { Ministry of Finance- } \\
\text { DEPP }\end{array}$ \\
\hline Types of controls & $\begin{array}{l}\text { Court of Audit Securities Ethics } \\
\text { Council (IPO in 2005) Statutory audi- } \\
\text { tor External auditors mandated by the } \\
\text { delegating authority }\end{array}$ & $\begin{array}{l}\text { Auditors External auditors man- } \\
\text { dated by the delegating authority }\end{array}$ & $\begin{array}{l}\text { Court of Audit } \\
\text { Statutory auditor }\end{array}$ \\
\hline Capital structure & $\begin{array}{l}51 \% \text { owned by Suez } 35 \% \text { owned by } \\
2 \text { institutional investors (CDG Group } \\
\text { and RMA Watanya) } 14 \% \text { free float }\end{array}$ & $100 \%$ Owned by Suez & $\begin{array}{l}100 \% \text { by the Moroccan } \\
\text { State }\end{array}$ \\
\hline Administration & $\begin{array}{l}\text { Board of directors including inde- } \\
\text { pendent directors }\end{array}$ & $\begin{array}{c}\text { by the sole partner via the Af- } \\
\text { rica Middle East and India Busi- } \\
\text { ness Unit }\end{array}$ & $\begin{array}{l}\text { Board of Directors } \\
\text { chaired by the Head of } \\
\text { Government }\end{array}$ \\
\hline $\begin{array}{l}\text { Percentage of man- } \\
\text { agers }\end{array}$ & High $(+16 \%)$ & High (-10\%) & High (+16\%) \\
\hline $\begin{array}{l}\text { Duration of the ac- } \\
\text { tivity }\end{array}$ & 30 years & 7 years (broken up early in 2018) & Nondefined \\
\hline $\begin{array}{l}\text { Status of employ- } \\
\text { ees }\end{array}$ & $\begin{array}{l}\text { Mostly statutory staff Minority con- } \\
\text { tract staff and expatriates }\end{array}$ & $\begin{array}{l}\text { Mostly contract staff Significant } \\
\text { percentage of municipal and } \\
\text { temporary staff }\end{array}$ & $\begin{array}{l}\text { Staff almost exclusive } \\
\text { statutory }\end{array}$ \\
\hline Paid by & Customer/User of the service & $\begin{array}{l}\text { The municipality based on a } \\
\text { statement established by the } \\
\text { company Casa Prestations }\end{array}$ & $\begin{array}{l}\text { Customer/User of the } \\
\text { service }\end{array}$ \\
\hline
\end{tabular}

The most relevant level for analyzing Appropriation is the community of practices (Wenger, 2009). The communities of practices identified for this research correspond to 2 categories of actors:

1. Specialists whose core business is either to design or animate the deployment of one of the management tools studied.

2. The users. These are managers and other executives who are supposed to use the tools and integrate them into their operations.

Results. The documentary content analysis phase was conducted on the basis of 28 coded documents. Almost $60 \%$ of the codes relate to the quality management system and $40 \%$ relate to the other 2 control tools. 

Internal Auditing Appropriation

The content analysis allowed us to establish a comparison between the 3 organizations on the basis of the criteria proposed in the theory of Lawrance \& Lorsh: Stability of the environment, New products of the sector, Prediction of competitors, Forecast of consumer preferences, Evolution and emergence of new scientific discoveries, Competitiveness, Regulatory constraints.

Inspired by the proposition of Lawrence and Lorsch who had indicated that if the environment is perceived as unstable and uncertain, the organization is more decentralized, less formalistic and more oriented towards mutual adjustment, and that if the environment is perceived as more stable and certain, the organization is more centralized, more formalized, an inconsistency between the organization put in place and the degree of instability of the environment at Urban Cleaning Company and at Public Office was noted.

The content analysis helps us to pre-identify certain plausible explanations (performance conception, impacts of organizational structure, planning, Digitalization, feedback comities, measurement methods, method of assessment of appropriation) to challenge during the following phases.

The responses collected during the perception study, also allowed us to suggest some hypotheses on the factors that could impact the simultaneous appropriation of the organizational control tools as follows:

- Integration of social dimensions and perceived quality in the design of performance.

- Impact of compliance and economic management tools.

- Deployment of ethical standards.

- Integration of the results of satisfaction surveys.

- Operational pressure (linked to a system of financial penalties applied by the regulatory or delegating authorities).

- Frequency of popularization efforts.

- Implementation of appropriation measurement tools.

- Concomitance with internal control, risk management and cost control systems.

- Specific nature of the deliverables of the control tools concerning the managed areas.

- The exhaustiveness of the processes covered by the management system.

- Existence of automated interfaces between functionalities and or between tools.

- Formal integration into managers' job descriptions.

- Existence of support for consolidating the actions and recommendations proposed by the different tools (FRAP, Dashboard, improvement log, etc.).

- Implementation of document management tools, API system, Business Intelligence tools, workflow management or mobile / WEB solutions.

- Link with disciplinary management.

- Responsiveness of IS services to respond to requests.

- Existence of a functional and decentralized sector.

- Budgetary decentralization.

- Existence of arbitration bodies about questions of layout and planning.

- The strong interface between management control and internal audit (initiation of performance topics) promotes ownership.

- The number of hierarchical levels.

- Presence of independent directors.

- Establishment of an ad hoc experience feedback committee.

- Frequency of organizational changes impacting capitalization.

- Sustainable activity (example: Duration of the delegated management contract).

- Financial transparency (obligation to publish activity reports, etc.).

- External recognition (certification, labelling, etc.). 

Internal Auditing Appropriation

The interviews conducted, enabled us to note that the question of measurement remains very complex to be grasped by the actors of the various organizations. The questionnaire disseminated enabled us to collect 223 response forms incorporating data relating to 45 coded variables.

The multiple component analysis applied to the appropriation measurement variables led to the following groups of responses: Private Company listed on the stock exchange market (Private company with a management contract for long term contract) to compare with Urban Cleaning Company (Private company with a management contract for a medium-term contract) and Public Office (Public Company).

Specialists of controlling to compare to Other managers. The second proposition is consistent with the level of analysis proposed in the design, which consists of understanding appropriation by a community of practice. Thanks to the «Machine Learning» functionalities of XL STAT, classification and regression trees were edited for the reduction of the data and to retain only the variables allowing better predictions and distinction between cases depending on the level of appropriation. Those variables are Diffusion of management controlling, Diffusion of the Quality Management System and Quality of appropriation of Quality Management System.

The differentiating measurement variables used to constitute the axial components of the parametric diagrams of the simultaneous appropriation of the organizational control tools proposed as constructs.

In summary, for each level of analysis (community of practice or organizational field), the process below was followed:

1. Generation of classification trees and regression tables allowing to establish the link between the differentiating measurement variables and each group of predictive variables (each group of variables corresponds to a phase of the process of appropriation).

2. Selection of predictor variables with the highest percentage of prediction vs. Reissue of new classification trees for the six measurement variables.

3. Consolidation of the highest prediction percentage in a single regression table.

4. Identification of the active measurement variable with the highest percentage of prediction.

5. Editing a correlation table (Pearson) to highlight the links and their intensity between the measurement variable in step e and the other measurement variables.

6. Consolidation of the results in a cognitive map also called a parametric diagram of the simultaneous appropriation of organizational control tools within the public service of the community of practice or of the research area analysed.

The dimension of simultaneity can lead to differences between the designed versions and the Appropriated versions. This gap corresponds to more than half of the functionalities of these tools. Thanks to this approach, 12 predictive factors were selected from a pool of 45 . The 4 factors «Accuracy of the outputs of internal audit», «ethical reference system», «integration of the social dimension» in the conception of the performance of the organization and formalization in the organizational reference systems such as the «files of management control attributions» are parameters to be taken into account when any change occurs within the organization. «Interfacing internal auditing and management controlling with satisfaction surveys», which implies the dimension of the perceived image of the public service, encouraging the use of certain «audit functionalities» internal and management control by managers, are 5 factors that can stimulate the implementation of the functionalities of organizational control tools. The regular deployment of content aimed at «popularizing management control and its functionalities», «formalizing clear interfaces between the quality management system and internal audit» as well as implementing «instance of Feedback» to debate around the output of control tools are 3 factors that promote organizational learning and enrich individual cognitive patterns that make it possible to explain the effects on performance.

These different stimuli of simultaneous appropriation do not act in the same way at the level of the different organizations studied. Thus, at Private Company listed on the stock exchange market and as the 

Internal Auditing Appropriation

measurement variables indicate, the level of Appropriation is higher compared to the other two organizations. The scheme specific to Private Company listed on the stock exchange market is focused on the stimulation of the measurement variable Diffusion of the Quality Management System influenced by the predictive variables, Integration of Management controlling in job descriptions, Functionalities used of the Quality Management system and Frequency of the popularization of the management control.

The axial measurement variable (Diffusion of the QMS) has a positive correlation with all the measurement variables. This correlation is more intense with the variables Quality of appropriation of the QMS, Diffusion of Internal Auditing, and quality of appropriation of Internal Audit. Public Office's scheme, focused on stimulating the measurement variable Diffusion Gestion de Gestion, is influenced by the predictive variables, Accuracy of internal auditing, Management involvement in planning, Quality Management System link with internal auditing missions. The axial measurement variable (Diffusion of management control) is correlated with the various measurement variables except those relating to Internal Audit. This correlation is intense with the variables Quality of ownership of management control and Quality of ownership of the Quality Management System. The scheme of The Urban cleaning private company, focused on the stimulation of the measurement variable Quality of appropriation of Management controlling, is influenced by the predictive variables, Social performance, Functionalities used of Management controlling, Frequency of popularization of management control and Ad hoc committees. The axial measurement variable (Quality of appropriation of management control) is correlated with the different measurement variables without exception. This correlation is intense with the variables Diffusion of management control and Quality of appropriation of the Quality Management System. Thanks to these predictive factors (Table 2), these organizations have between $39 \%$ and $62.5 \%$ chance of reaching a good level on one of the dimensions of the measurement of appropriation used this analysis.

Table 2. Schemes of simultaneous appropriation

\begin{tabular}{|c|c|c|c|c|c|}
\hline $\begin{array}{c}\text { Case / Community of } \\
\text { practice }\end{array}$ & $\begin{array}{l}\text { Active variable to pre- } \\
\text { dict }\end{array}$ & $\begin{array}{l}\text { Predictive } \\
\text { strength }\end{array}$ & Discontinuity & Selection & Retention \\
\hline Utilities PrivateCompany & $\begin{array}{l}\text { QMS Diffusion (dissemi- } \\
\text { nation) }\end{array}$ & $63 \%$ & $\begin{array}{l}\text { Integration of QMS } \\
\text { in Job Descriptions }\end{array}$ & $\begin{array}{l}\text { Usedfeaters } \\
\text { of QMS }\end{array}$ & $\begin{array}{c}\text { Frequency of } \\
\text { popularization of } \\
\text { Management } \\
\text { controlling }\end{array}$ \\
\hline $\begin{array}{l}\text { Urban cleaning private } \\
\text { company }\end{array}$ & $\begin{array}{l}\text { Qualité of appropriation } \\
\text { of Management control- } \\
\text { ling }\end{array}$ & $39 \%$ & $\begin{array}{l}\text { Internal Auditing } \\
\text { outputs accuracy } \\
\text { and precision }\end{array}$ & $\begin{array}{l}\text { Used fea- } \\
\text { tures of Man- } \\
\text { agement } \\
\text { Controlling }\end{array}$ & $\begin{array}{l}\text { Frequency of } \\
\text { popularization of } \\
\text { Management } \\
\text { controlling }\end{array}$ \\
\hline Public Office & $\begin{array}{l}\text { Management controlling } \\
\text { Diffusion (Dissemina- } \\
\text { tion) }\end{array}$ & $46 \%$ & Ethics & $\begin{array}{l}\text { Organization } \\
\text { of Manage- } \\
\text { ment control- } \\
\text { ling }\end{array}$ & $\begin{array}{c}\text { Financial Trans- } \\
\text { parency }\end{array}$ \\
\hline Users & $\begin{array}{l}\text { QMS Diffusion(dissemi- } \\
\text { nation) }\end{array}$ & $31 \%$ & $\begin{array}{l}\text { Integration of Man- } \\
\text { agement controlling } \\
\text { in Job Descriptions }\end{array}$ & $\begin{array}{l}\text { satisfaction } \\
\text { surveys into } \\
\text { Internal au- } \\
\text { diting }\end{array}$ & $\begin{array}{l}\text { Responsiveness } \\
\text { of Information } \\
\text { Systems }\end{array}$ \\
\hline Specialists & QMS Diffusion(dissemination) & $55 \%$ & $\begin{array}{l}\text { Ethics / Internal Au- } \\
\text { diting outputs accu- } \\
\text { racy and precision / } \\
\text { Integration of Man- } \\
\text { agement controlling } \\
\text { in Job Descriptions }\end{array}$ & $\begin{array}{l}\text { Used features of } \\
\text { QMS / Integra- } \\
\text { tion of Satisfac- } \\
\text { tion surveys in } \\
\text { Management } \\
\text { controlling / In- } \\
\text { volvement of } \\
\text { Management in } \\
\text { planning }\end{array}$ & $\begin{array}{l}\text { Financial } \\
\text { Transpar- } \\
\text { ency }\end{array}$ \\
\hline
\end{tabular}

Sources: developed by the author 
N., Baldi. Management of Innovations in Public Governance:Quality Management System, Management Controlling and Internal Auditing Appropriation

Those factors influence the active axial measurement variable to predict (presenting the highest rate of prediction). As indicated in the correlation matrix (Table 3), the main variables to be predicted have a positive correlation ( between $r=0,101$ and $r=0,791$ ) with the other measurement variables except for the non-specialists managers community and the public company (between $r=-0,516$ and $r=-0,099$ ).

Through the correlation between the 6 measurement variables to predict (Table 3), the 12 prediction variables previously indicated, these organizations may have a chance between $30 \%$ and $80 \%$ of having a good level of simultaneous appropriation (Table 4).

Table 3. The findings of correlations analysis

\begin{tabular}{|c|c|c|c|c|c|c|c|c|}
\hline \multirow{2}{*}{$\begin{array}{l}\text { Case / Commu- } \\
\text { nity of practice }\end{array}$} & \multicolumn{2}{|c|}{$\begin{array}{c}\text { Active variable to pre- } \\
\text { dict }\end{array}$} & \multicolumn{6}{|c|}{ Correlation } \\
\hline & 1 & 2 & 3 & 4 & 5 & 6 & 7 & 8 \\
\hline $\begin{array}{l}\text { Utilities Private- } \\
\text { Company }\end{array}$ & Diffusion SMQ & $63 \%$ & 0,71 & 0,48 & 0,04 & 1,00 & 0,10 & 0,55 \\
\hline $\begin{array}{l}\text { Urban cleaning pri- } \\
\text { vate company }\end{array}$ & $\begin{array}{l}\text { Qualité Controle } \\
\text { de gestion }\end{array}$ & $39 \%$ & 0,20 & 0,35 & 0,45 & 0,25 & 1,00 & 0,52 \\
\hline Public Office & $\begin{array}{l}\text { Diffusion Con- } \\
\text { trole de gestion }\end{array}$ & $46 \%$ & 0,15 & $-0,04$ & 1,00 & 0,31 & 0,47 & $-0,52$ \\
\hline Users & Diffusion SMQ & $31 \%$ & 0,79 & 0,40 & 0,43 & 1,00 & 0,09 & 0,55 \\
\hline Specialists & Diffusion $S M Q$ & $55 \%$ & 0,30 & 0,28 & $-0,18$ & 1,00 & $-0,10$ & 0,42 \\
\hline
\end{tabular}

1 - Active variable to predict; 2 - Predictive strength; 3 - Internal Auditing Dissemination / Diffusion; 4 - Internal Auditing Quality of appropriation; 5 - Management controlling Diffusion / Dissemination; 6 - QMS Diffusion / Dissemination; 7 - Management Controlling Quality of appropriation; 8 - QMS Quality of Appropriation.

Sources: developed by the author

Table 4. The findings of regression analysis

\begin{tabular}{|c|c|c|c|c|c|c|c|c|c|}
\hline \multirow{2}{*}{$\begin{array}{l}\text { Case / Com- } \\
\text { munity of } \\
\text { practice }\end{array}$} & \multicolumn{2}{|c|}{ Predictive variable } & \multicolumn{7}{|c|}{ Variable to predict, $\%$} \\
\hline & Discontinuity & Selection & Retention & 1 & 2 & 3 & 4 & 5 & 6 \\
\hline $\begin{array}{l}\text { Utilities Pri- } \\
\text { vateCompany }\end{array}$ & $\begin{array}{l}\text { Integration of } \\
\text { QMS in Job De- } \\
\text { scriptions }\end{array}$ & Usedfeaters of QMS & $\begin{array}{l}\text { Frequency of popu- } \\
\text { larization of Manage- } \\
\text { ment controlling }\end{array}$ & 44 & 38 & 25 & 63 & 25 & 44 \\
\hline $\begin{array}{l}\text { Urban clean- } \\
\text { ing private } \\
\text { company }\end{array}$ & Ethics & $\begin{array}{l}\text { Organization of Man- } \\
\text { agement controlling }\end{array}$ & $\begin{array}{l}\text { Financial Transpar- } \\
\text { ency }\end{array}$ & 55 & 9 & 73 & 23 & 64 & 0 \\
\hline Public Office & $\begin{array}{l}\text { Internal Auditing } \\
\text { outputs accuracy } \\
\text { and precision }\end{array}$ & $\begin{array}{l}\text { Used features of } \\
\text { Management Control- } \\
\text { ling }\end{array}$ & $\begin{array}{l}\text { Frequency of popu- } \\
\text { larization of Manage- } \\
\text { ment controlling }\end{array}$ & 11 & 7 & 29 & 18 & 39 & 18 \\
\hline Users & $\begin{array}{l}\text { Integration of } \\
\text { Management } \\
\text { controlling in Job } \\
\text { Descriptions }\end{array}$ & $\begin{array}{l}\text { Integration of satis- } \\
\text { faction surveys into } \\
\text { Internal auditing }\end{array}$ & $\begin{array}{l}\text { Responsiveness of } \\
\text { Information Systems }\end{array}$ & 74 & 10 & 80 & 74 & 60 & 10 \\
\hline Specialists & $\begin{array}{l}\text { Ethics / Internal } \\
\text { Auditing outputs } \\
\text { accuracy and } \\
\text { precision / Inte- } \\
\text { gration of Man- } \\
\text { agement control- } \\
\text { ling in Job De- } \\
\text { scriptions }\end{array}$ & $\begin{array}{l}\text { Used features of } \\
\text { QMS / Integration of } \\
\text { Satisfaction surveys } \\
\text { in Management con- } \\
\text { trolling / Involvement } \\
\text { of Management in } \\
\text { planning }\end{array}$ & $\begin{array}{l}\text { Financial Transpar- } \\
\text { ency }\end{array}$ & 20 & 20 & 15 & 20 & 55 & 20 \\
\hline
\end{tabular}

Sources: developed by the author. 
The processes implemented within the public service must explicitly integrate the dimension of social performance. Social performance presupposes the integration of quantitative and or qualitative measures on the social climate and conditions of intervention of employees as well as action plans to promote social and environmental responsibility.

Social management control is a variant of management control based on socio-economic dimensions which allows these organizations to operationalize this concept. Among other things, it deals with remuneration systems, job and skills management and the social climate (Martory, 2015).

Social auditing as a variant of auditing, is a regulatory tool enabling a balance to be struck between economic and social performance through the preservation of working conditions, health and safety measures, the implementation of a flexible work organization that meets both the expectations of users or customers and those of employees.

The integration of standards like the ISO 26000 standard is a tool for progress in a logic of social responsibility and permanent and participative progress, respectful of the environment, respectful of agents, and men and women outside, all by ensuring economic sustainability (D. Gauthier).

Professionalizing performance management presupposes the establishment of coordination committees such as the Audit Committee, Processor Management Review within the framework of the management system, the Business Review for management control.

The implementation of the functionalities of performance control and in this case management control must be explicitly indicated in the function sheet defining the prerogatives and attributions of the executives and managers of said organizations.

In the frame of reference on which the internal audit should be based, it is recommended to integrate elements relating to the satisfaction of users or customers of the organization. Another approach for taking this aspect into account would be to draw up the internal audit plan, considering the conclusions emerging from satisfaction surveys.

How the quality management system is implemented has a strong influence on the implementation of the other control instruments. Insisting on features like continuous improvement logs, document management and process reviews would stimulate simultaneous appropriation.

Confusion persists today in the minds of public service managers about internal audit. Is it an instrument for securing processes or a function aiming at continuous improvement more in the role of advice? It is relevant to deploy popularization procedures for internal audit regularly to correct misconceptions. These popularization approaches allow the positive cognitive anchoring of this function near managers.

The functioning of the organizational divisions in charge of information systems within the framework of a Service Level Agreement system integrating, among other things, a satisfactory level of responsiveness promotes the simultaneous appropriation of the various control instruments.

Integration of the dimension of simultaneity:

Certain factors make it possible to integrate the dimension of simultaneity and to draw favourable effects in this case in terms of appropriation of control tools within a public service such as the deployment of an internal control system (Cardoso, 2010, Ji et al., 2020, Lartey et al., 2020) which enables a value judgment to be made on the quality of management and, in general, on the proper functioning of the various departments of the organization. Internal control consists in verifying whether preventive control measures are effectively implemented by the actors of the organization on the one hand and whether these measures remain efficient taking into account the evolution of risks, benchmarks and the organization.

Internal control, combined with managerial control, budgetary control and third-party control, completes the panorama of control systems. Also, consolidating progress plans in a single monitoring tool is a measure that helps to denoise piloting processes and to focus attention by neutralizing unproductive 

Internal Auditing Appropriation

redundancies. This consolidation process would simplify the selection and management of actions by assessing their impacts on the one hand and their feasibility on the other.

The formalization (via contracts) of certain requirements impose the integration and implementation of certain control functionalities. This factor can take many forms. Contractual review in the case of delegated management contracts, or minutes of joint boards of directors in the case of public establishments. This formalization stimulates the observability of the effects of control tools.

The observability of the effects when it also materializes by external recognition or by the enhancement of the outputs of the different tools by integrating them into internal or external communication plans induces simultaneous appropriation.

The establishment of coordination committees or functional channels promotes the simultaneous appropriation of control tools within the public service.

The proposed simultaneous appropriation schemes can constitute food for thought in organizations with similar characteristics than the studied cases. The differences between the schemes can be explained by the characteristics of the 3 types of organization, more particularly the characteristics relating to the perception by the actors of the level of stability of the environment, of the requirement in terms of communication. financial, the nature of the risks to which the organization is exposed, the organizational choices in terms of centralization or decentralization of certain sectors.

Other organizational dimensions also impact the simultaneous appropriation such as the process interfaces in this case between Internal Audit and QMS and between Management Control and Internal Audit. The deployment of a centralized arbitration process promotes simultaneous appropriation. This type of arbitration on aspects of planning and implementation allows the modelling of certain functional interactions. The way of using a control tool can have effects on the appropriation of other control tools as demonstrated in the previous analysis. This approach based on the principle of stimulating an axial measurement variable has the advantage of making it possible to denoise analyses and orient the action plans to be undertaken, even if the links between the measurement variables to be predicted and the others measurement variables do not have the same intensity. The model of the publicly traded private enterprise, the public institution and the specialist community have higher predictive power compared to those of the other cases. Correlation matrices between measurement variables allow to integrate the dimension of simultaneity in a certain way. The simultaneous appropriation model proposed for the case of the private company listed on the stock exchange and the user community model makes it possible to best integrate the dimension of simultaneity given the number of strong correlations noted between the different variables. of measurement (3 correlations/6).

In a managerial logic, the proposed schemes make it possible to evaluate the process of simultaneous appropriation by constituting a structured analysis grid as follows:

1. Analysis of the differences between the narrative versions and those implemented by identifying the functionalities implemented.

2. Diagnosis of predictive variables.

3. Assessment of managers' perception of the Diffusion and Quality of ownership dimensions.

Conclusions. Technological, sociological and economic evolutions etc of the modern era lead public service companies to set up a myriad of new tools. The integration of these tools and their mutual interactions can induce, if not considered, harmful effects on the performance of the organization at various levels. The simultaneous appropriation of organizational control tools is complex because of the number of predictive factors that can induce effects on its level and because of the number of variants of the simultaneous appropriation schemes (depending on the nature of the public service or the nature of the communities of practice to target).

In terms of theoretical contributions, this research has enabled the proposal of 5 schemes of simultaneous appropriation (Table 2). These schemes constitute a reformulation of the conception of De Vaujany. 

Internal Auditing Appropriation

They also address the question of measuring appropriation by proposing to combine two measurement dimensions, Diffusion, corresponding to the percentage of users and quality of appropriation, corresponding to the perceived gaps between the potential functionalities and the functionalities implemented.

In terms of managerial perspective, these schemes can be used to assess organizational control processes, the results of which can be monitored over time. In terms of methodological contributions, this research proposes an analytical approach to establish the link between explanatory factors and a multitude of variables to be explained, through a factorial analysis based on the principle of transitivity and this according to the scheme next to the identification of the active predictors, classification trees applied to these active variables, identification of the axial active variable with the highest predictive power and correlation matrix with the other predictors. The proposal of an axial measurement variable correlated to the other measurement variables allowed the integration of the dimension of simultaneity which is a contextual and contingency dimension which should not be hidden. The integration of these contextual dimensions reinforces the relevance of the schemes as recommended in numerous researches (Ferreira \& Otley, 2009). This research can be enriched by other complementary reflections formulated in the following questions:

1. Can these models be transposed to other types of objects (CSR policy, ethics, IS, etc.) or to organizations with similar characteristics, even those of private services? Multi-client Vs Single client? Is the analysis methodology followed transposable to other organizational control instruments, in this case nonformal? How the proposed models can be modified to integrate some such as technological and digital developments? Are these models strongly linked to the dimension of interculturality? or sociological as the question of generations (Millennials vs. other generations)? How can cost-benefit assessment approaches be integrated into the proposed models?

2. The integration of the dimension of simultaneity in addition to giving this research research its original character makes it possible to adopt a more pragmatic posture because this allows to get closer to the reality of the organizations studied. Simultaneity is a dimension that helps to anchor cooperation, a culture of collaboration and the development of a shared vision.

Acknowledgment. This article is the result of a research involving several contributors whom I would like to thank. Particularly, Dr. David Huron and Dr. Abdelmajid Ibenrissoul for the quality of the supervision as well as Dr. Elisabeth Walliser, Director of Laboratoire GRM de l' Institut d'Administration des Entreprises de Nice de l'Université de la Cote d'Azur.

\section{References}

Akrich, M (1993). Les formes de la médiation technique. Réseaux, La Découverte, pp.87-98. Retrieved from https://halshs.archives-ouvertes.fr/halshs-00081741

Berrebi-Hoffmann, I., \& Boussard, V. (2005). Avant-propos. Au nom de la norme: gouvernance et outils de gestion. Sociologies pratiques, 10(1), 1-6. [CrossRef]

Brignall, S., \& Modell, S. (2000). An institutional perspective on performance, measurement and management in the «new public sector». Management Accounting Research, 11(3), 281-306. [Google Scholar] [CrossRef]

Cardoso, A. (2010). Le suivi de l'efficacité des systèmes de controle interne et de gestion des risques, Les travaux de l'IFA, France, 2-24. Retrieved from https://www. auditsi.eu/?wpfb dl=21

Chia, R. (1996). The problem of reflexivity in organizational research: Towards a postmodern science of organization. Organization, 3(1), 31-59. [Google Scholar] [CrossRef]

Creswell, J. W. (2003). Research design: Qualitative, quantitative, and mixed methods approaches (2nd ed.). Thousand Oaks, CA: Sage. [Google Scholar]

De Vaujany, F. X. (2006). Pour une théorie de l'appropriation des outils de gestion : vers un dépassement de l'opposition conception-usage. Management Avenir, 3, 109-126. [Google Scholar]

Ferreira, A. \& Otley, D. (2009). The design and use of performance management systems: An extended framework for analysis. Management Accounting Research, 20(4), 263-282. [CrossRef]

Gauche, K. (2013). Typologie de pratiques de gestion et indices d'appropriation. 34ème congrès de l'AFC, Canada. [Google $\underline{\text { Scholar] }}$ 
N., Baldi. Management of Innovations in Public Governance:Quality Management System, Management Controlling and Internal Auditing Appropriation

Giddens, A. (1987). La constitution de la société. Paris, PUF. Retrieved from https://www.persee.fr/doc/polix 02952319 1988 num_1 322014

Grandgirard, A. (2007). De la gestion intégrée comme doctrine à lintégration comme défi de gestion. (Doctoral dissertation). [Google Scholar]

Grimand, A. (2006). L'appropriation des outils de gestion : vers de nouvelles perspectives théoriques? Université de SaintEtienne [Google Scholar]

Hanzlick, M., \& Bruhl, R. (2013). Management Control Systems as a package, CIMA, Allemagne. [Google Scholar]

Ji, X., \& Kaplan, S. E., Lu, W., \& Qu, W. (2020), The role of voluntary internal control reporting in earnings quality: Evidence from China. Journal of Contemporary Accounting and Economics, 100188. [Google Scholar] [CrossRef]

Lartey, P. Y., \& Kong, Y., Bah, F. B. M., Santosh, R. J., \& Gumah, I. A. (2020). Determinants of Internal Control Compliance in Public Organizations; Using Preventive, Detective, Corrective and Directive Controls. International Journal of Public Administration, 43(8), 711-723. [Google Scholar] [CrossRef]

Lawrence, P. R., \& Lorsch, J. W. (1967). Differentiation and Integration in Complex Organizations. Administrative Science Quarterly, 1-47. [Google Scholar] [CrossRef]

Martory, B. (2015). Le controle de gestion social (8ème édition). Vuibert. [Google Scholar]

Peirce, Ch. S. (1978). Écrits sur le signe (rassemblés, traduits et commentés par G. Deledalle), Paris, Seuil.

Quach, S., \& Thaichon, P., \& Hewege, C. (2020). Triadic relationship between customers, service providers and government in a highly regulated industry. Journal of Retailing and Consumer Services, 55, 102148. [Google Scholar] [CrossRef]

Rogers, M. (1998). The definition and Measurement of Innovation. The Univercity of Melbourne [Google Scholar]

Silaen, P., \& Williams, R (2009). Management control systems: a model for R\&D units. Accounting Research Journal. [Google Scholarl

Silva, R. C. D. (2003). Les nouveaux mécanismes du controle organisationnel. Cadernos Ebape. br, 1(2), 01-23

Usunier, J.C. (2000). Confiance et performance: un essai de management comparé France-Allemagne. [Google Scholar]

Van de Ven, A. H. (2007). Engaged scholarship: A guide for organizational and social research. Oxford University Press on Demand. [Google Scholar]

Wanlin, P. (2007). L'analyse de contenu comme méthode d'analyse qualitative d'entretiens: une comparaison entre les traitements manuels et l'utilisation de logiciels. Recherches qualitatives, 3(3), 243-272. [Google Scholar]

Weick, K. E. (1995). Sensemaking in Organizations. Sage Publications, Thousand Oaks California. [Google Scholar]

Wenger, E. (2009). Communities of practice. Communities, 22(5). [Google Scholar]

Набіл Балді,

Iнститут ділового адміністрування Ніцци, Франція

Менеджмент інновацій в публічному управлінні: система управління якістю, адміністративний контроль та внутрішній аудит

Ця стаття узагальнює аргументи та контраргументи в межах наукової дискусії з питання менеджменту інновацій в публічному управлінні. Вказано, що специсріка впровадження інновацій в публічному управління має свої характерні особливості, які полягають у впровадженні системи організаційного контролю. здійснено аналіз елементів системи організаційного контролю: система управління якістю, адміністративний контроль, внутрішній аудит, які впливають на процеси прийняттяя рішень та результативності діяльності. Окреслюються специсрічні фрункціональні можливості досліджуваних інструментів: внутрішній аудит застосовується для перевірки відповідності процедур; адміністративний контроль застосовується в області управління бюджетуванням; система якісного менеджменту застосовується для регламентації процедур. Зазначено, що попри значні потенційні можливості вищезазначених інструментів, недостатня еффективність та фррагментарність їх використовуються не приносять значного синергетичного ефектту. Основною метою проведеного дослідження $\varepsilon$ виявлення факторів, що дозволяють сприятливо впливати на ефективність впровадження системи організаційного контролю в громадських організаціях. Об'єктом дослідження є три громадські організації в Марокко. В статті представлено результати емпіричного аналізу, який засвідчив необхідність зміни системи менеджменту досліджуваних організацій на основі врахування дії двох факторів: одночасності (тобто одночасному впровадженні досліджуваних інструментів) та оригінальності асигнувань. За результатами дослідження запропоновано низку доповнень до моделі асигнувань Де Вауяні, а саме уточнення факторів прогнозування, які впливають на кожен етап процесу асигнування досліджуваних інструментів контролю (внутрішній аудит, адміністративний контроль та система якісного менеджменту). Результати проведеного дослідження можуть бути корисними для громадських організацій при проведенні оцінки ефрективності запровадження інструментів організаційного контролю та вибору напрямів стимулювання їх використання.

Ключові слова: асигнування, сумісність, єдина система, внутрішній контроль, державне управління

Manuscript received: 11.02.2020

(C) The author(s) 2020. This article is published with open access at Sumy State University. 